\title{
"Continued discussion on conventional versus Islamic banks: combining financial ratios and efficiency"
}

\begin{tabular}{|c|c|}
\hline AUTHORS & $\begin{array}{l}\text { Mohammad Imdadul Haque (D https://orcid.org/0000-0001-6323-032X } \\
\text { Mohammad Rumzi Tausif (D https://orcid.org/0000-0001-7485-9385 } \\
\text { Anis Ali (D) https://orcid.org/0000-0001-7799-6043 }\end{array}$ \\
\hline ARTICLE INFO & $\begin{array}{l}\text { Mohammad Imdadul Haque, Mohammad Rumzi Tausif and Anis Ali (2020). } \\
\text { Continued discussion on conventional versus Islamic banks: combining financial } \\
\text { ratios and efficiency. Banks and Bank Systems, 15(1), 132-142. } \\
\text { doi:10.21511/bbs.15(1).2020.13 }\end{array}$ \\
\hline DOI & http://dx.doi.org/10.21511/bbs.15(1).2020.13 \\
\hline RELEASED ON & Wednesday, 25 March 2020 \\
\hline RECEIVED ON & Thursday, 20 February 2020 \\
\hline ACCEPTED ON & Monday, 16 March 2020 \\
\hline LICENSE & $\begin{array}{l}(c)) E Y \\
\text { This work is licensed under a Creative Commons Attribution } 4.0 \text { International } \\
\text { License }\end{array}$ \\
\hline JOURNAL & "Banks and Bank Systems" \\
\hline ISSN PRINT & $1816-7403$ \\
\hline ISSN ONLINE & $1991-7074$ \\
\hline PUBLISHER & LLC "Consulting Publishing Company "Business Perspectives" \\
\hline FOUNDER & LLC "Consulting Publishing Company "Business Perspectives" \\
\hline
\end{tabular}

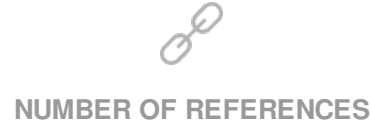

35

\section{NUMBER OF FIGURES}

0

\section{E= $=$}

NUMBER OF TABLES

5

(C) The author(s) 2022. This publication is an open access article. 


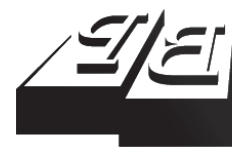

\section{BUSINESS PERSPECTIVES}

LLC "CPC "Business Perspectives" Hryhorii Skovoroda lane, 10, Sumy, 40022, Ukraine www.businessperspectives.org
Received on: 20 $0^{\text {th }}$ of February, 2020 Accepted on: $16^{\text {th }}$ of March, 2020 Published on: $25^{\text {th }}$ of March, 2020

(c) Mohammad Imdadul Haque, Mohammad Rumzi Tausif, Anis Ali, 2020

Mohammad Imdadul Haque, Ph.D. Associate Professor, Department of Management, College of Business Administration, Prince Sattam Bin Abdulaziz University, Saudi Arabia.

Mohammad Rumzi Tausif, Ph.D., Assistant Professor, Department of Management, College of Business Administration, Prince Sattam Bin Abdulaziz University, Saudi Arabia.

Anis Ali, Ph.D., Assistant Professor, Department of Management, College of Business Administration, Prince Sattam Bin Abdulaziz University, Saudi Arabia.
Mohammad Imdadul Haque (Saudi Arabia), Mohammad Rumzi Tausif (Saudi Arabia), Anis Ali (Saudi Arabia)

\section{CONTINUED DISCUSSION ON CONVENTIONAL VERSUS ISLAMIC BANKS: COMBINING FINANCIAL RATIOS AND EFFICIENCY}

\begin{abstract}
Two different types of banking systems, Islamic and conventional, dominate the banking structure in Saudi Arabia. The purpose of this paper is to contribute to the ongoing debate as to which of the two is better. Using data for the period 2014-2018, the study compares Islamic and conventional banks. It combines traditional financial ratios, Return on Assets (ROA) and Return on Equity (ROE), with Data Envelopment Analysis (DEA) to perform a comprehensive analysis. In terms of ROA, the performance of conventional banks is better than that of Islamic banks, but in terms of ROE, vice versa. DEA results show that conventional banks are more efficient than Islamic banks. In fact, in terms of ROA and ROE, Al Rajhi Bank, an Islamic bank, is the best performer. But in terms of efficiency scores from DEA, Al Rajhi ranks seventh among all banks, while NCB, a conventional bank, ranks first. Issuing shares and utilizing funds in profitable options, such as loans and advances to increase net income, are the policy recommendations for Islamic banks to further improve. In addition, as the study finds no correlation between the ratio and efficiency scores, it proposes to use a combined measure of ratio analysis and efficiency analysis for a comprehensive assessment of bank performance.
\end{abstract}

\section{Keywords}

bank performance, return on assets, data envelopment analysis, correlation, Saudi Arabia

\section{JEL Classification $\quad$ G21, Z12}

\section{INTRODUCTION}

Islamic banking is the banking structure that operates in accordance with the law of Islamic jurisprudence (Sharia). Islamic jurisprudence prohibits interest, uncertainty, gambling, pre-determined fixed returns; any types of overcharging, getting fixed money on loans are forbidden (Haram). A tangible/physical asset supports all transactions in an Islamic bank (Hassan, Khan, Amin, \& Khokhar, 2018). Sharia forbids investing in businesses that are prohibited (Haram) in Islam, like gambling, alcohol, pornography, pork, etc. (Khokhar \& Sillah, 2014). Like any conventional bank, Islamic banks also perform basic functions. The main products of Islamic banks are 'Mudarabah, Musharakah, Salam, Ijarah, Qard-e-Hasna and Murabaha' (Salman \& Nawaz, 2018). These names stand for the principle of profit and loss sharing, partnerships and joint ventures, sales contracts, leasing contracts, interest-free loans and trade with mark-up, respectively.

Islamic banking is steadily growing in the global financial market. The success of Islamic banking system is not limited only to Muslim countries. It is gaining popularity in countries such as UK and USA (Lone, Aldawood, \& Bhat, 2017). The regulation of Islamic banking 
transactions differs from that of a conventional bank. A team of Islamic (sharia) scholars govern the operations of an Islamic bank. The Sharia board is responsible for compliance with Islamic principles in all banking operations. More than six hundred financial institutions and banks operate worldwide on the principles of Islamic banking. There are several multinational banks offering Islamic banking services to a wider population, not only to Muslims, but also non-Muslims around the world (Hassan, Khan, Amin, \& Khokhar, 2018).

Although Islamic banking is an old concept, it gained a lot of attention after the 2008 crises. After 2008, about 120 banks, including US giant Lehman Brothers, filed for bankruptcy, while Islamic banks remained resilient in times of crisis. Hence, they reported fewer losses, and most of them survived that crisis. Since then, Islamic banking has gained a lot of interest among academicians, financial and banking experts. This sound experience of Islamic banks has led researchers to claim that it 'survived the test of time' (Oseni \& Hassan, 2010), and that this financial crisis was a 'test of resilience' for the Islamic banks and it proved to be an alternative to conventional banking (Hassan, 2018).

The basic difference between the two banking systems is that conventional banks depend on interest, while Islamic banks depend on the principles of profit and loss sharing. Islamic banking services are basically of three different categories. The first category, free services, includes current account functions, such as 'overdraft, demand loans' and the like. Here, the profit and loss sharing in not possible. Profit and loss sharing happens in the other category of services, such as 'equity financing, hire purchase, leasing' and the like. The second category involves fixed charge/fee/commissions. And the major revenue earning is the third category of services dealing with indirect investment in a bank's own projects, investment auctioning, commodity trade, spot transaction in foreign exchange and the like (Oseni \& Hassan, 2010).

Islamic banking has the risk sharing, whereas in conventional banking, the customer transfers the risk to the bank and in turn receives a guaranteed fixed return. Theoretically, Islamic banking is resistant to surprise shocks (Alghfais, 2017). Besides, in conventional banking, customers pay interest that does not depend on the project return (Qian \& Veluyathan, 2017). This is due to its focus on risk sharing, limited risk taking and strong association with real activities (Hussain, Shahmoradi, and Turk, 2015). Islamic banking works based on the unique concept of maximizing the 'equal distribution of income' (Alanazi \& Lone, 2016). Islamic banks depend primarily on sales-type products, which have lower risk than conventional debt-based products (Kabir, Worthington, \& Gupta, 2014).

In Saudi Arabia, there are 12 listed banks. The market share of these banks is as follows: National Commercial Bank (20\%), Al Rajhi Bank (16\%), Riyadh Bank \& Samba Financial Group (10\%), Banque Saudi Fransi, Saudi British Bank \& Arab National Bank (8\%), Alinma Bank (8\%), Saudi Investment Bank \& Alawwal Bank (4\%), Bank AlJazira \& Albilad bank (3\%) (AlJazira Capital, 2018). Out of these, four banks are Islamic banks. The overall share of Islamic banks is around $30 \%$. This study plans to study and compare the performance of Islamic banks and conventional banks in Saudi Arabia.

\section{LITERATURE REVIEW}

Previous studies compared Islamic banks with conventional banks in Saudi Arabia. Miah and Uddin (2017) conducted a comprehensive study for the period 2005 to 2014 using regression and Stochastic Frontier Analysis (SFA). In general, about 48 conventional and 28 Islamic banks of Gulf countries were studied. Results show that conventional banks have managed their cost more efficiently than Islamic banks. However, Islamic banks have done better in terms of short-term solvency but with regard to long-term solvency, there is not much difference between the two.

Loghod (2010) compared profitability, liquidity and structure of Islamic and conventional banking systems from 2000 to 2005 using a logit model for 
the banks in GCC countries. The results showed no significant difference in terms of profitability. However, Islamic banks are less open to liquidity risk. Conventional banks are more dependent on external liabilities. The study found no statistical significant differences in internal growth rate for Islamic and conventional banks. According to the study, performance depends on the management style and the bank's general performance.

Effendi and Disman (2017) conducted a comprehensive study in seven countries, including Saudi Arabia. Data was analyzed from 2009 to 2015 using panel data regression. The study included 12 conventional and 20 Islamic banks. However, the results are mixed, as there is no clear-cut result that can suggest which style of banking is better.

Ghassan and Taher (2015) compared the financial robustness and stability of Islamic banks and conventional banks. The study found Islamic banks to be more financially stable than conventional banks. It also revealed low competition amongst banks in Saudi Arabia that affected the financial stability. The study expressed concern that the lower share of Islamic banks in the overall banking sector of Saudi Arabia hinders any improvements in the financial stability of the sector.

Al-turki (2014) studied nine commercial banks and three Islamic banks in Saudi Arabia for 20052011 using a linear panel data model. According to his study, there is no significant difference between Islamic banks and conventional bank for all variables except for the bank cost.

Kabir, Worthington, and Gupta (2014) studied the credit risk of 37 Islamic and 156 conventional banks for the period 2000-2012. The banks were from 13 different countries, including Saudi Arabia. The authors acknowledged the issues of using only accounting ratios. They used accounting information of the Z-score and nonperforming loan (NPL) ratio and compared the results with Merton's distance-to-default (DD) model. This DD model is a market-based credit risk measure. The results indicated that, compared to conventional banks, Islamic banks had lower credit risk in terms of a DD model and higher risks in terms of the $\mathrm{Z}$-score and NPL ratio.
Saif-Alyousfi, Saha, and Md-Rus (2017) compared Islamic and conventional banks in terms of the CAMEL model parameters for the period 20002015 using Tobin's Q, Market-to-book ratio, and ROE using pooled OLS and a random effect model. The study found that the Islamic banks contribution to shareholder value is greater than that of conventional banks. Higher capital ratio and credit risk in conventional banks led to weakened shareholder value, while Islamic banks did not have such a problem. Moreover, higher level of loans lowered shareholders value in conventional banks' shareholder value, while it resulted in an increase in Islamic banks. In addition, conventional banks with higher liquidity have lower shareholder value, while it was vice versa in Islamic banks.

Alghfais (2017) studied four Islamic and eight conventional banks in Saudi Arabia for the period 1988 to 2016 using a binary logistic regression method. The study suggests that Islamic banks are more profitable and have lower risk, their contribution in the economic growth is greater, and they have higher capitalization compared to conventional banks. However, conventional banks have better investment portfolios and are more efficient. Since Islamic banks have high capitalization, they are able to use it for high profitability, but they do not have standardized products. The researchers opined that it might be the reason why Islamic banks are less efficient compared to conventional banks.

Brown, Hassan, and Skully (2007) studied the operational efficiency of Islamic banks for the period 1998 to 2003 for 11 countries, including Saudi Arabia. They found that conventional banks were more stable in terms of loan portfolio. The reason may be more effective management practices, as conventional banks are much older. Islamic banks were better in terms of net financing to total assets. This could be due to the concept of equity financing, when Islamic banks work as joint partners in the projects.

After searching for further studies, the researchers found some works on the overall banking structure using a ratio analysis. Almazari and Almumani (2012) explored the profitability efficiency of banks in Saudi Arabia during the period 2006-2010. They used return on assets and 
operating income. One important finding of this study was that high total assets did not result in high profit.

Medabesh (2012) studied the determinants of Saudi banks' profitability during the period 1990 2008. The author used ROA and ROE in the analysis. It was found that the banks were decreasing the exposure to risk, had good international reputation, and generated profits from long-run investments. Due to these characteristics, the author commended the safety of banks in Saudi Arabia from bankruptcy and high credibility.

Sillah, Khokhar, and Khan (2014) analyzed the technical efficiency of Saudi banking in 2000-2011. They categorized banks in Saudi Arabia as follows: Saudi-foreign owned, Saudi owned, and Islamic banks. The banks were compared in terms of deposit mobilization, investment allocation and income generation. Saudi-foreign owned banks are judged as the best group of banks. Banque Saudi Fransi was identified as the benchmark and it was found that performance of banks solely owned by Saudi Arabia fluctuated and there was no difference between Saudi owned banks and Islamic banks.

Other researchers analyzed banks' activities using DEA. AlKhathlan and Malik (2010) calculated the efficiency of 10 banks of Saudi Arabia using Data Envelopment Analysis (DEA) for the period 2003-2008. The results indicated that the mean efficiency as constant returns to scale in terms of managing financial resources of the sample banks increased from $81.91 \%$ in 2003 to $86.78 \%$ in 2008 . Only four banks, namely, Al Rajhi Bank, Banque Saudi Fransi, Saudi British Bank and Hollandi Bank, had $100 \%$ scores for the year 2008. Using constant returns to scale, during the overall period, Al Rajhi Bank and Banque Saudi Fransi were more efficient, while NCB was the least efficient.

Almumani (2013) applied DEA with constant returns to scale for the data on 10 Saudi banks for the period 2007-2011. The inputs were total deposits and total expenses, while the outputs were total loans and advances and net investment. Using constant returns to scale, the average technical efficiency ranged from $94.23 \%$ to $99.28 \%$. Banque Saudi Fransi and ANB had the highest efficiency scores of more than 99\%, while Riyadh Bank,
Albilad and Saudi Holland Bank had the lower score (about 94\%). Banque Saudi Fransi ranked first and SHP had the last position in terms of average efficiency for the period of study.

Hassan, Khan, Amin, and Khokhar (2018) used DEA, where the inputs were deposits, assets and capital and the outputs were investments, advances and income for the period 2008-2016. Using constant returns to scale, the study compared four Islamic banks operating in Saudi Arabia and found that Al Rajhi Bank was the best bank followed by Bank AlJazira, Alinma and Al Bilad.

Hassan (2006) explored the relative efficiency of Islamic banks for the period 1995-2001, using panel data from 43 banks from 21 countries, including Saudi Arabia. The author used both parametric and non-parametric methods. The input variables were labor, fixed capital, customers and short-term funding. The output variables were total loans, other earning assets and off-balance sheet items. The study found that conventional banks were more efficient than Islamic banks. Technical efficiency was better than allocative efficiency. Also, scale efficiency was greater than technical efficiency. Another key finding was that the efficiency results were correlated with ROA and ROE and it was recommended that they be used simultaneously.

The above literature indicates that there are quite a few studies on the performance of Saudi Arabian banks. However, the debate on Islamic banks compared to conventional banks is still inconclusive, as studies show different results. This study aims to continue the discussion and provide conclusive evidence of which form of banking is best.

\section{METHODS}

Data on banks' deposits, loans and assets are from the websites of respective banks and Saudi Arabian Monetary Agency. The process of measuring bank performance is divided into two categories, namely traditional and frontier approaches (Varadi, Pradeep, \& Boppana, 2006). The traditional approach uses accounting ratios to measure overall financial performance (Karim \& Alam, 2013). Return on Assets (ROA) and Return 
on Equity (ROE) are some of the common used items for the ratio analysis. The second category, a frontier approach, includes both parametric and non-parametric methods to establish a mathematical relationship between variables, Stochastic Frontier Approach (SFA) and Data Envelopment Analysis (DEA) (Azari \& Abadi, 2013; Kumar \& Gulati, 2008; Tahir, Bakar, \& Haron, 2009).

ROA is used to analyze the secondary data and information to fulfill the research requirement. Return on total assets is the relationship between net income and total assets of an organization; it reveals the operational efficiency of the business organization. This ratio shows the use of the resources, i.e. how efficiently a business utilizes its resources to generate income. A high return on assets ratio shows the maximum utilization of the resources and considers it favorable for the business organization.

$$
R O A=\frac{\text { Profit before tax }}{\text { Total assets }} .
$$

Return on equity is the relationship between net income from business operations and shareholder equity and reveals the profitability or return for the real owner of the corporation. A high return on equity is favorable for the business organization and indicates how shareholders are getting returns on their invested funds in the business organization.

$$
R O E=\frac{\text { Profit after tax }}{\text { Equity capital }} .
$$

Next, Data Envelopment Analysis (DEA) is used to measure efficiency. DEA compares different units based on inputs and outputs and is used to find relative efficiency of banks. DEA can be performed using DEA Online Software (DEAOS), Basic Radial Models (Envelopment Forms), Input Oriented, and Constant Returns to Scale (CRS). The inputs will be the deposits and capital, and the output will be income. The model for DEA is given below.

\section{For maximization problem:}

$D M U_{m}$ uses $x_{i j}$ of input $n$, and $n=$ deposits, capital; $t_{n}$ is weights assigned to $n^{\text {th }}$ input; $D M U_{m}$ yields $y_{o m}$ of output $t$, and $t=$ net income; $q_{t}$ is weights assigned to $t^{\text {th }}$ output, where $m=1,2,3 \ldots, 12$.
Let $D M U_{n}=D M O_{o},\left(\right.$ for $\left.o^{\text {th }} D M U\right)$;

$$
\operatorname{Max}_{o}(q, r)=\frac{\sum_{r} q_{s} y_{s o}}{\sum_{i} r_{i} x_{i o}} .
$$

Subject to, $\frac{\sum_{s} q_{s} y_{s j}}{\sum_{i} r_{i} x_{i j}} \leq 1$,

for $m=1,2,3 \ldots, 14$; and $q_{s}, r_{i} \geq 0$, for all $n$ and $s$

According to Mukherjee, Nath, and Pal (2002), Mittal and Dhingra (2007), there are methodological limitations of using accounting ratios like ROA to measure bank performance, as it provides inadequate information on resource utilization, economies of scale, benchmarking and overall measurement of performance. Moreover, a single ratio must be compared with a benchmark and does not provide a reference unit for the poor performer. DEA is better because it deals with multiple inputs and outputs and classifies units as efficient and inefficient with respect to a unit whose efficiency is equal to one. Hence, it suggests the reference unit for which inefficient units can be compared.

Studies have shown that in many cases, banks tend to be more concerned with sustained profitability rather than efficiency (Murthy et al., 2008). Therefore, it is proposed to supplement ROA with performance indicators such as income. Towards this, Cronjé and de Beer (2010) and Oberholzer, Van der Westhuizen, and Van Rooyen (2010) have combined ROA with the DEA scores for South African banks. A recent study exclusively for Saudi Arabia is missing. A related study by Hassan (2006) did include Saudi Arabia in its panel of sample countries but considered the data for the period up to 2001 . Much has changed in the banking sector of Saudi Arabia since 2001, and one need to carefully study the period after the financial crisis of 2008. Thus, the significance of this study is that it will establish the relationship between ratio analysis and DEA performance indicators for banks in Saudi Arabia.

Kabir, Worthington, and Gupta (2014) have shown that assessments of bank performance change using different methods, therefore, it is proposed to combine and use different methods 
to measure bank performance. In addition, after an extensive review of existing studies, Hassan and Sirajo (2016) conclude that Islamic and conventional banking systems work according to different principles and, therefore, the method for studying one system may not be suitable for studying another. The study recommended methodological research.

\section{RESULTS}

\subsection{ROA (return on assets)}

ROA of twelve banks of Saudi Arabia is shown in Table 1. From the table, it is clear that return on assets of Al Rajhi Bank, Samba Financial Group and Saudi British Bank are satisfactory. It indicates sound operational performance of the banking industry in Saudi Arabia. The earning capacity of AlJazira (1.37), Saudi Investment Bank (1.42), Alawwal Bank (1.50), Bank Albilad (1.59) and Arab National Bank (1.76) is below the average of the Saudi banking industry (1.85). The performance of Riydh Bank (1.85), Banque Saudi Fransi (1.87), Saudi British Bank (2.32), Samba Financial Group (2.26), Al Rajhi Bank (2.47) and National Commercial Bank (2.14) is above the average of the Saudi banking industry.

$50 \%$ (2 out of 4 ) of Islamic banks have ROA ratio lower than the average ROA of the overall banking sector. While only $25 \%$ (2 out of 8 ) of conventional banks have ROA ratio lower than the overall banking sector on average. As per average ranking of yearly ROA ratios, Al Rajhi Bank, Samba Financial Group and Saudi British Bank utilize their resources optimally and have better returns.

\subsection{ROE (return on equity)}

ROE of twelve banks of Saudi Arabia is shown in Table 2. The table shows that ROE of $\mathrm{Al}$ Rajhi Bank, National Commercial Bank and Saudi British Bank is satisfactory and indicates sound returns for owners. The owners' returns of Alinma Bank (8.90), Bank AlJazira (11.21), Riyadh Bank (11.01) and Saudi Investment Bank (10.33) are below the average of ROE of the Saudi banking industry. Return on equity of Alawwal Bank (12.00), Banque Saudi Fransi (12.28) and Samba Financial Group (12.39) is approximately near to average of the Saudi banking industry. Al Rajhi Bank (16.96), National Commercial Bank (16.76), Saudi British Bank (14.26) and Bank Albilad (12.92) are giving return to shareholders above the average (12.66) of the Saudi banking industry.

$50 \%$ (2 out of 4 ) of Islamic banks have a lower ROE ratio than the overall sector average, while about $62 \%$ (5 out of 8 ) of conventional banks have a lower ROE than the sector average. According to the average ranking of annual ROE, Al Rajhi Bank, National Commercial Bank and Saudi British Bank provide better returns to their shareholders.

Table 1. Return on assets

\begin{tabular}{|c|c|c|c|c|c|c|c|c|c|c|c|c|}
\hline Years & 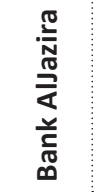 & 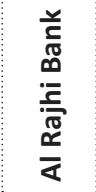 & 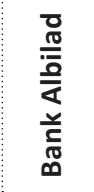 & 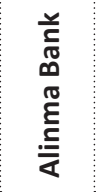 & 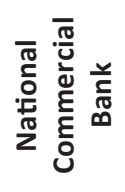 & $\begin{array}{l}\text { 并 } \\
\frac{D}{D} \\
0 \\
\frac{c}{D} \\
\frac{\lambda}{\alpha}\end{array}$ & 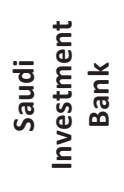 & $\sum_{\frac{\pi}{\sigma}}^{\pi} \frac{v}{\frac{1}{\sigma}}$ & 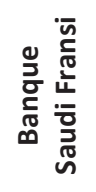 & 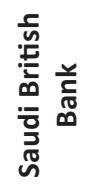 & 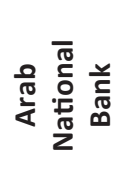 & 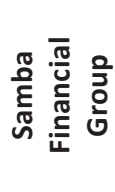 \\
\hline & Ratio & Ratio & Ratio & Ratio & Ratio & Ratio & Ratio & Ratio & Ratio & Ratio & Ratio & Ratio \\
\hline 2014 & 0.86 & 2.22 & 1.91 & 1.56 & 1.99 & 1.84 & 1.53 & 1.88 & 1.86 & 2.27 & 1.75 & 2.3 \\
\hline 2015 & 2.03 & 2.26 & 1.54 & 1.66 & 2.02 & 1.5 & 1.42 & 1.87 & 2.2 & 2.31 & 1.74 & 2.22 \\
\hline 2016 & 1.31 & 2.39 & 1.5 & 1.43 & 2.11 & 1.86 & 1.12 & 1.01 & 1.73 & 2.09 & 1.68 & 2.16 \\
\hline 2017 & 1.26 & 2.66 & 1.49 & 1.75 & 2.21 & 2.01 & 1.5 & 1.34 & 1.83 & 2.11 & 1.76 & 2.21 \\
\hline 2018 & 1.37 & 2.82 & 1.51 & 2.07 & 2.35 & 2.05 & 1.52 & 1.38 & 1.74 & 2.82 & 1.86 & 2.4 \\
\hline $\begin{array}{l}\text { Average } \\
\text { performance }\end{array}$ & 1.37 & 2.47 & 1.59 & 1.7 & 2.14 & 1.85 & 1.42 & 1.5 & 1.87 & 2.32 & 1.76 & 2.26 \\
\hline Ranks & 12 & 1 & 9 & 8 & 4 & 6 & 11 & 10 & 5 & 2 & 7 & 3 \\
\hline Average & \multicolumn{4}{|c|}{1.78 (Islamic banks) } & \multicolumn{8}{|c|}{1.89 (Conventional banks) } \\
\hline Average & \multicolumn{12}{|c|}{1.68 (All banks) } \\
\hline
\end{tabular}


Table 2. Return on equity

\begin{tabular}{|c|c|c|c|c|c|c|c|c|c|c|c|c|}
\hline \multirow[t]{2}{*}{ Years } & 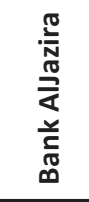 & 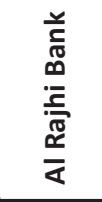 & 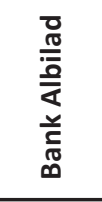 & 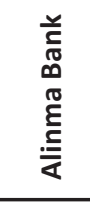 & 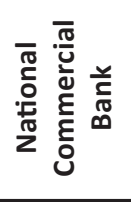 & 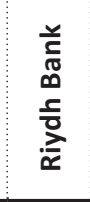 & 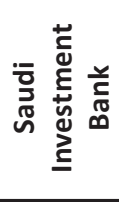 & $\begin{array}{l}\bar{\pi} \\
\sum_{3} \\
\frac{1}{\pi} \\
\frac{\pi}{4}\end{array}$ & 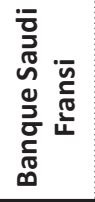 & 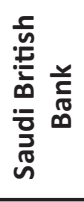 & 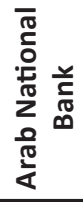 & 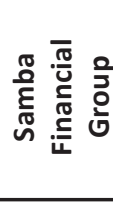 \\
\hline & Ratio & Ratio & Ratio & Ratio & Ratio & Ratio & Ratio & Ratio & Ratio & Ratio & Ratio & Ratio \\
\hline 2014 & 9.3 & 16.32 & 14.67 & 7.05 & 19.14 & 11.1 & 12.12 & 16.95 & 13.29 & 16.36 & 13.96 & 12.9 \\
\hline 2015 & 17.36 & 15.29 & 12.24 & 8.01 & 16.78 & 9.15 & 11.04 & 16.82 & 14.69 & 15.37 & 13.54 & 12.95 \\
\hline 2016 & 10.76 & 15.64 & 11.09 & 7.83 & 15.86 & 10.72 & 7.77 & 8.28 & 11.82 & 12.45 & 12.28 & 11.72 \\
\hline 2017 & 9.71 & 16.36 & 12.41 & 9.77 & 15.55 & 11.27 & 9.88 & 9.82 & 11.16 & 11.86 & 12.42 & 11.26 \\
\hline 2018 & 8.9 & 21.21 & 14.18 & 11.82 & 16.48 & 12.82 & 10.85 & 8.16 & 10.45 & 15.24 & 12.51 & 13.1 \\
\hline $\begin{array}{l}\text { Average } \\
\text { performance }\end{array}$ & 11.21 & 16.96 & 12.92 & 8.9 & 16.76 & 11.01 & 10.33 & 12 & 12.28 & 14.26 & 12.94 & 12.39 \\
\hline Ranks & 9 & 1 & 5 & 12 & 2 & 10 & 11 & 8 & 7 & 3 & 4 & 6 \\
\hline Average & \multicolumn{4}{|c|}{12.49 (Islamic banks) } & \multicolumn{8}{|c|}{12.74 (Conventional banks) } \\
\hline Average & & & & & & s. & anks) & & & & & \\
\hline
\end{tabular}

\subsection{Efficiency analysis}

The efficiency scores of the twelve banks of Saudi Arabia are calculated using Data Envelopment Analysis. The inputs are deposits and capital and the output is income. Out of four Islamic banks, only Al Rajhi (25\% of the total Islamic banks) has an efficiency score higher than the overall industry average, while four of the eight banks, namely National Commercial Bank, Saudi Investment Bank, Arab National Bank and Samba Financial Group (50\% of the total conventional banks), have an efficiency score higher than overall. In addition, in the last year included in the study (that is, 2018), only two out of four banks had a $100 \%$ efficiency score, while six out of eight banks had an efficiency score of hundred percent (Table 3).

\subsection{Bank ranking}

When the banks are compared in terms of broad categories of Islamic banks and conventional banks (Table 4), the composite score for conventional banks (5.79) is higher than that of the Islamic banks (7.92). According to ROA and ROE analysis, performance of Al Rajhi Bank, Saudi British Bank and National Commercial Bank is satisfactory, while the performance of Bank AlJazira, Saudi Investment Bank and Alinma Bank is below the industry average. There is a difference in the performance of banks according to ROA and ROE analysis. This difference is because the difference of profit before tax and total assets is included in ROA and that of profit after tax and shareholder funds is included in ROE. The reason

Table 3. Efficiency scores

\begin{tabular}{|c|c|c|c|c|c|c|c|c|c|c|c|c|}
\hline Years & 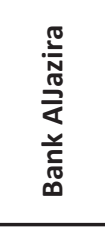 & 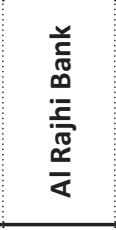 & 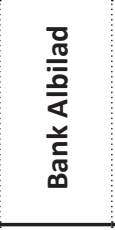 & 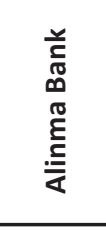 & 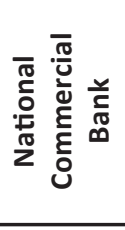 & 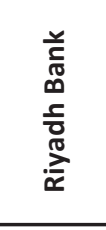 & 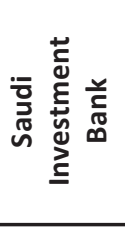 & $\begin{array}{l}\frac{y}{c} \\
\frac{1}{10} \\
0 \\
\frac{\pi}{\pi} \\
\frac{3}{0} \\
\frac{\pi}{4}\end{array}$ & 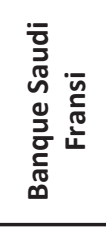 & 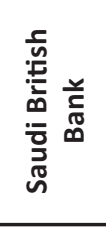 & 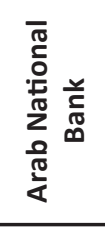 & 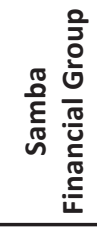 \\
\hline 2014 & $44.50 \%$ & $76.20 \%$ & $100 \%$ & $76.20 \%$ & $88.30 \%$ & $86.10 \%$ & $100 \%$ & $100 \%$ & $87.10 \%$ & $100 \%$ & $94.40 \%$ & $100 \%$ \\
\hline 2015 & $100 \%$ & $79.40 \%$ & $79.40 \%$ & $80.30 \%$ & $92.70 \%$ & $71.90 \%$ & $90.40 \%$ & $96 \%$ & $100 \%$ & $82.40 \%$ & $93 \%$ & $93.70 \%$ \\
\hline 2016 & $67.70 \%$ & $85.10 \%$ & $81.30 \%$ & $66.70 \%$ & $95.10 \%$ & $91.90 \%$ & $72.80 \%$ & $52.60 \%$ & $87 \%$ & $75.90 \%$ & $89.40 \%$ & $89.60 \%$ \\
\hline 2017 & $66.60 \%$ & $95.30 \%$ & $80.40 \%$ & $80.90 \%$ & $100 \%$ & $100 \%$ & $93.90 \%$ & $72 \%$ & $87.50 \%$ & $77.50 \%$ & $94.70 \%$ & $92 \%$ \\
\hline 2018 & $73.20 \%$ & $100 \%$ & $85.70 \%$ & $100 \%$ & $100 \%$ & $100 \%$ & $100 \%$ & $73.90 \%$ & $81.90 \%$ & $100 \%$ & $100 \%$ & $100 \%$ \\
\hline $\begin{array}{l}5 \text { year } \\
\text { average }\end{array}$ & $70.40 \%$ & $87.20 \%$ & $85.36 \%$ & $80.82 \%$ & $95.22 \%$ & $89.98 \%$ & $91.42 \%$ & $78.90 \%$ & $88.70 \%$ & $87.16 \%$ & $94.30 \%$ & $95.06 \%$ \\
\hline Ranks & 12 & 7 & 9 & 10 & 1 & 5 & 4 & 11 & 6 & 8 & 3 & 2 \\
\hline Average & \multicolumn{4}{|c|}{ 80.95\% (Islamic banks) } & \multicolumn{8}{|c|}{ 90.09\% (Conventional banks) } \\
\hline Average & \multicolumn{12}{|c|}{$87.04 \%$ (All banks) } \\
\hline
\end{tabular}


for the proportional difference between ROA and $\mathrm{ROE}$ is excessive taxes, interest expenses and external liabilities in the balance sheet of banks.

According to the ratio analysis of banks in Saudi Arabia, Al Rajhi, Saudi British Bank and National Commercial Bank have better performance, while Saudi Investment Bank, Alinma Bank and Alawwal Bank have the lowest performance according to ranks provided based on ratio analysis. There is a huge difference in performance scores between AlRajhi Bank among Islamic banks and Saudi Investment Bank and Saudi British Bank among conventional banks. Al Rajhi Bank ranks first in ROA and ROE but seventh in DEA. Saudi Investment Bank ranks eleventh in ROA and ROE but fourth in DEA.

Table 4. Ranking of banks

\begin{tabular}{|c|c|c|c|c|}
\hline Name & ROA & ROE & DEA & Average rank \\
\hline Bank AlJazira & 12 & 9 & 12 & 11 \\
\hline Al Rajhi Bank & 1 & 1 & 7 & 3 \\
\hline Bank Albilad & 9 & 5 & 9 & 7.67 \\
\hline Alinma Bank & 8 & 12 & 10 & 10 \\
\hline \multicolumn{4}{|c|}{ Overall average for Islamic banks } & 7.92 \\
\hline National Commercial Bank & 4 & 2 & 1 & 2.33 \\
\hline Riyadh Bank & 6 & 10 & 5 & 7 \\
\hline Saudi Investment Bank & 11 & 11 & 4 & 8.67 \\
\hline Alawwal Bank & 10 & 8 & 11 & 9.67 \\
\hline Banque Saudi Fransi & 5 & 7 & 6 & 6 \\
\hline Saudi British Bank & 2 & 3 & 8 & 4.33 \\
\hline Arab National Bank & 7 & 4 & 3 & 4.67 \\
\hline Samba Financial Group & 3 & 6 & 2 & 3.67 \\
\hline \multicolumn{4}{|c|}{ Overall average for conventional banks } & 5.79 \\
\hline
\end{tabular}

\subsection{Rank correlation}

Two distinct cases are evident from the difference in ranks from ratios and DEA. First, Saudi Investment Bank properly uses its deposits to receive advances and generate income on its advances distributed among their beneficiaries, as it is fourth in DEA. However, the bank is not able to properly utilize its total assets, as it ranks 11th in terms of ROA and ROE. Meanwhile, Al Rajhi Bank properly uses its total assets, as it is first in ROA and ROE, but the return on input, such as equity capital and deposits, is lower than desired. Better ROA performance means good returns on a bank's total assets. Better ROE performance means better returns on equity capital. Better performance in DEA means more income from equity capital and deposits.
In addition, an attempt was made to correlate between ranks of ROA, ROE and DEA using Spearman's rank correlation coefficient (Table 5 ). The high degree of a significant positive correlation (0.692) between ROA and ROE is quite expected, as both of them are accounting ratios of more or less similar nature. However, no significant correlation was found between the ranks of ROA and ROE and ranks of DEA. In addition, this justifies the usage of two tools (ratios and efficiency) to measure performance. This would give a more comprehensive view of bank performance.

Table 5. Correlation analysis

\begin{tabular}{|c|c|c|c|c|c|}
\hline \multicolumn{3}{|c|}{ Correlations } & $\begin{array}{c}\text { Rank } \\
\text { ROA }\end{array}$ & $\begin{array}{c}\text { Rank } \\
\text { ROE }\end{array}$ & $\begin{array}{c}\text { Rank } \\
\text { DEA }\end{array}$ \\
\hline \multirow{9}{*}{ 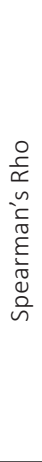 } & \multirow{3}{*}{$\begin{array}{l}\text { Rank } \\
\text { ROA }\end{array}$} & $\begin{array}{l}\text { Correlation } \\
\text { coefficient }\end{array}$ & 1.0 & $0.692 * *$ & 0.462 \\
\hline & & Sig. (1-tailed) & 0.0 & 0.006 & 0.065 \\
\hline & & $\mathrm{N}$ & 12 & 12 & 12 \\
\hline & \multirow{3}{*}{$\begin{array}{l}\text { Rank } \\
\text { ROE }\end{array}$} & $\begin{array}{l}\text { Correlation } \\
\text { coefficient }\end{array}$ & $0.692 * *$ & 1.0 & 0.329 \\
\hline & & Sig. (1-tailed) & 0.006 & 0.0 & 0.148 \\
\hline & & $\mathrm{N}$ & 12 & 12.0 & 12.0 \\
\hline & \multirow{3}{*}{$\begin{array}{l}\text { Rank } \\
\text { DEA }\end{array}$} & $\begin{array}{l}\text { Correlation } \\
\text { coefficient }\end{array}$ & 0.462 & 0.329 & 1 \\
\hline & & Sig. (1-tailed) & 0.065 & 0.148 & 0.0 \\
\hline & & $\mathrm{N}$ & 12 & 12 & 12 \\
\hline
\end{tabular}

Note: $* *$ Correlation is significant at the 0.01 level (1-tailed).

A similar idea has been presented earlier by Hassan (2006) but a correlation was found between the two different types of measures and it was recommended to use them simultaneously. But this study finds no correlation between accounting ratios and efficiency scores. The difference in the results of these two studies may be due to the study period or the sample of countries or the choice of inputs and outputs in DEA. Although this study finds no correlation between accounting ratios and efficiency scores, it still recommends the adoption of both measures for a more comprehensive measurement of performance.

\section{DISCUSSION}

The present study indicates that the performance of conventional banks is better than that of Islamic banks. Despite using different variables and methods, the results of this study contradict Alghfais (2017), Saif-Alyousfi, Saha, and Md-Rus (2017), 
Sillah, Khokhar, and Khan (2014), Ghassan and Taher (2015) who found Islamic banks better than conventional banks. The current study reports that in terms of ROA, the performance of conventional banks is better than that of Islamic banks. However, in terms of ROE, the performance of Islamic banks is better than that of conventional banks. Moreover, DEA results show that conventional banks are more efficient than Islamic banks.

The results point to the need for AlJazira, Saudi Investment Bank and Alawwal Bank to enhance net income, minimize blockage of funds, minimize operational expenses, invest more funds in profitable options to increase ROE. Riyadh Bank, Saudi
Investment Bank and AlJazira Bank should try to increase their net income by reducing operating expenses and managing funds from cheaper sources. These banks have performed poorly in terms of ROE.

To improve financial performance, Islamic banks, such as Bank AlJazira and Alinma Bank, have to minimize their interest expenses by managing funds form cheaper sources or issuing shares. However, tax liability of a bank cannot be minimized and issuing of shares will be the option in the hands of banks to manage monetary requirement in future. Besides, Al Rajhi Bank must utilize its deposits or available funds to profitably distribute funds as loans and advances to increase net profit.

\section{CONCLUSION}

Islamic and conventional baking systems are two different types systems common in Saudi Arabia. Therefore, this study attempts to establish which of the two systems is better for banks. The study innovates by combining two different approaches to measure bank performance, namely: financial ratios and efficiency analysis. Financial ratios, such as ROA and ROE, give conflicting results, while efficiency analysis using DEA indicates that conventional banks are more efficient than Islamic banks. Finally, the study recommends Islamic banks issue more shares and use their funds in profitable ventures. The study also advocates combining different measures to assess bank performance.

Though applying different principles of lending and borrowing, both the Islamic and conventional banking systems have the same goal. The results show that Islamic banks are better in terms of managing their returns on equity, while conventional banks are better in maintaining efficiency; therefore, both banking systems can learn from each other for further improvement. Islamic banks can learn in terms of managing their assets from conventional banks as they are more experienced and more widespread. Conventional banks can provide an option of Islamic banking products to those who are interested, which will increase their customer base. This can lead to further diversification of banking services, which ultimately will benefit everyone.

\section{AUTHOR CONTRIBUTIONS}

Conceptualization: Mohammad Imdadul Haque.

Data curation: Mohammad Rumzi Tausif, Anis Ali.

Formal analysis: Mohammad Rumzi Tausif.

Investigation: Mohammad Imdadul Haque.

Methodology: Mohammad Rumzi Tausif, Anis Ali.

Project administration: Mohammad Imdadul Haque.

Resources: Anis Ali.

Software: Mohammad Rumzi Tausif.

Supervision: Mohammad Imdadul Haque.

Validation: Mohammad Imdadul Haque.

Visualization: Mohammad Imdadul Haque.

Writing - original draft: Mohammad Imdadul Haque.

Writing - reviewing \& editing: Mohammad Rumzi Tausif, Anis Ali. 


\section{REFERENCES}

1. Alanazi, E. S. M., \& Lone, F. A. (2016). Social Satisfaction towards Islamic Banking in Saudi Arabia: A Survey. Asian Social Science, 12(1), 1911-2025. https://doi. org/10.5539/ass.v12n1p182

2. Alghfais, M. (2017). A Comparative Study between Islamic and Conventional BanksThe case of Saudi Arabia: A Binary Logistic Regression Approach (SAMA Working Paper WP/17/4). Financial Sector Development Department, Saudi Arabian Monetary Authority. Retrieved from http://www.sama.gov.sa/ en-US/EconomicResearch/ WorkingPapers/A\%20Comparative $\% 20$ Study $\% 20$ between $\% 20$ Islamic\%20and\%20conventional\%20Banks\%20A\%20Binary\%20 Logistic.pdf

3. AlJazira Capital. (2018). Saudi Banking Sector Quarterly Report, 3Q-2018. Retrieved from https:// www.aljaziracapital.com.sa/report_ file/ess/SEC-611.pdf_(accessed 30 September 2019).

4. AlKhathlan, K., \& Malik, S. M. (2010). Are Saudi Banks Efficient? Evidence Using Data Envelopment Analysis (DEA). International Journal of Economics and Finance, 2(2), 53-58. https://doi. org/10.5539/ijef.v2n2p53

5. Almazari, A. A., \& Almumani, M. A. (2012). Measuring Profitability Efficiency of the Saudi National Banks. International Journal of Business and Social Science, 3(14), 176-185. Retrieved from https:// pdfs.semanticscholar.org/bbb9/ $142 \mathrm{e} 5 \mathrm{~b} 49 \mathrm{cc} 44 \mathrm{f} 041829 \mathrm{efa} 3325 \mathrm{~d}-$ fc4936583.pdf

6. Almumani, M. A. (2013). The Relative Efficiency of Saudi banks: Data Envelopment Analysis. International Journal of Academic Research in Accounting, Finance and Management Science, 3(3), 152-161. https://doi.org/10.6007/ IJARAFMS/v3-i3/115

7. Al-turki, K. H. (2014). Islamic Banks versus Commercial Banks and Performance: The Context of Saudi Arabia? Global Journal of Management and
Business Research: D Accounting and Auditing, 14(1), 32-44. Retrieved from https://www. semanticscholar.org/paper/ Islamic-Banks-versus-Commercial-Banks-and-The-of-Al-turki/ c7d296b9a4d903d5605c1e9063d$3 \mathrm{~d} 25 \mathrm{e} 5 \mathrm{~d} 2 \mathrm{~d} 8 \mathrm{ac} 9$

8. Azari, A., \& Abadi, N. (2013). Studying the Performance Evaluation Results with Parametric and Non- Parametric Methods (Banking Industry). Journal of Basic and Applied Scientific Research, 3(4), 453-462. Retrieved from http://www.textroad.com/pdf/JBASR/J.\%20Basic.\%20Appl.\%20Sci.\%20Res.,\%20 3(4)453-462,\%202013.pdf

9. Brown, K., Hassan, M. K., \& Skully, M. (2007). Operational Efficiency and Performance of Islamic Banks. In M. K. Hassan, \& M. K. Lewis (Eds.), Handbook of Islamic Banking (96-115). Cheltenham: Edward Elgar. Retrieved from https://research. monash.edu/en/publications/ operational-efficiency-and-performance-of-islamic-banks

10. Cronjé, T., \& de Beer, J. (2010). Combining Efficiency with ROA: Indicator of Future Relative Performance - South African banking groups. Corporate Ownership and Control, 7(4-2), 287-296. https://doi.org/10.22495/ cocv7i4c $2 \mathrm{p} 4$

11. Effendi, K. A., \& Disman, D. (2017). Liquidity Risk: Comparison between Islamic and Conventional Banking. European Research Studies Journal, XX(2A), 308-318. Retrieved from https://www.ersj.eu/repec/ers/ papers/17_2_A_p18.pdf

12. Ghassan, H. B., \& Taher, F. B. (2015). Financial Stability of Islamic and Conventional Banks in Saudi Arabia: Evidence using Pooled and Panel Models (MPRA Paper No. 54472). Retrieved from https://mpra.ub.uni-muenchen. de/92889/3/MPRA_paper_92889. pdf

13. Hassan, M. K. (2006). The $\mathrm{X}$-Efficiency in Islamic Banks. The
Islamic Research and Training Institute (IRTI), 13(2), 50-78.

Retrieved from https://ideas.repec. org/a/ris/isecst/0062.html

14. Hassan, M. K. (2018). The Global Financial Crisis and Islamic Finance. SSRN. http://dx.doi. org/10.2139/ssrn.3263920

15. Hassan, M. K., \& Sirajo, A. (2016). An Empirical Literature Survey of Islamic Banking. SSRN. http:// dx.doi.org/10.2139/ssrn.2980516

16. Hassan, M., Khan, M. N., Amin, M. F. B., \& Khokhar, I. (2018). Measuring the Performance of Islamic Banks in Saudi Arabia International. Journal of Economics and Management, 12(1), 99-115. Retrieved from https://www.researchgate.net/ publication/326941568_Measuring_the_performance_of_islamic_ banks_in_Saudi_Arabia

17. Hussain, M., Shahmoradi, A., \& Turk, R. (2015). An Overview of Islamic Finance (IMF Working Papers WP/15/120). International Monetary Fund. Retrieved from https://www.imf.org/external/ pubs/ft/wp/2015/wp15120.pdf

18. Kabir, N., Worthington, A. C., \& Gupta, R. (2014). Comparative Credit Risk in Islamic and Conventional Banks. Pacific-Basin Finance Journal, 34. http://dx.doi. org/10.2139/ssrn.2491951

19. Karim, R., \& Alam, T. (2013). An Evaluation of Financial Performance of Private Commercial Banks in Bangladesh: Ratio Analysis. Journal of Business Studies Quarterly, 5(2), 65-77. Retrieved from https:// www.researchgate.net/publication/282734488_An_Evaluation_of_Financial_Performance_ of_Private_Commercial_Banks_ in_Bangladesh_Ratio_Analysis

20. Khokhar, I., \& Sillah, B. M. S. (2014). Consumer Perceptions on Islamic Banks: The Case of Saudi Arabia. Journal of Islamic Banking and Finance, 31(4), 70-81. Retrieved from https://fac.ksu.edu. sa/sites/default/files/consumer_ perceptions_on_islamic_banks_ the_case_of_saudi_arabia.pdf 
21. Kumar, S., \& Gulati, R. (2008). An Examination of Technical, Pure Technical, and Scale Efficiencies in Indian Public Sector Banks using Data Envelopment Analysis. Eurasian Journal of Business and Economics, 1(2), 33-69. Retrieved from https://www.ejbe.org/ EJBE2008Vol01No02p33KUMARGULATI.pdf

22. Loghod, H. A. (2010). Do Islamic Banks Perform Better than Conventional Banks? Evidence from Gulf Cooperation Council countries (API Working Paper API/WPS 1011). Kuwait: Arab Planning Institute, Information Center. Retrieved from http:// www.arab-api.org/jodep/products/ delivery/wps1011.pdf

23. Lone, F. A., Aldawood, E. B., \& Bhat, U. R. (2017). Comparative Analysis of Customer Satisfaction towards Islamic and Conventional Banking: An Empirical Study from Saudi Arabia. International Review of Management and Marketing, 7(1), 273-280. Retrieved from https://www.econjournals.com/index.php/irmm/ article/view/3775/pdf

24. Medabesh, A. (2012). The Determinants of Saudi Islamic Bank profitability. Global Advanced Research Journal of Management and Business Studies, 1(10), 339-344. Retrieved from http://garj.org/full-articles/thedeterminants-of-saudi-islamicbank-profitability.pdf

25. Miah, M., \& Uddin, H. (2017). Efficiency and Stability: A Comparative Study between Islamic and Conventional banks in GCC countries. Future Business Journal, 3(2), 172-185. https://doi. org/10.1016/j.fbj.2017.11.001

26. Mittal, R. K., \& Dhingra, $S$. (2007). Assessing the Impact of Computerization on Productivity and Profitability of Indian Banks: an application of data envelopment analysis. Delhi Business Review, 8(1), 63-73. Retrieved from https:// pdfs.semanticscholar.org/ c0f0/d752212ec9e5599979abb5a5ce7ce109befc.pdf?_ga =2. 86376784.950357457.1584686358-2100778558.1584432533
27. Mukherjee, A., Nath, P., \& Pal, M. N. (2002). Performance Benchmarking and Strategic Homogeneity of Indian Banks. The International Journal of Bank Marketing, 20(3), 122-139. https://doi. org/10.1108/02652320210430965

28. Oberholzer, M., Van der Westhuizen, G., \& Van Rooyen, S. (2010). The Influence of Banks' Internal Performance On Market Performance: A Non-Parametric Approach. Southern African Business Review, 14(2), 65-88. Retrieved from http://www.ajol. info/index.php/sabr/article/viewFile/76370/66829

29. Oseni, U., \& Hassan, M. K. (2010). The Emergence and Development of Islamic Banking. In Islamic Finance: Instruments and Markets (pp. 113-117). Bloomsbury. United Kingdom. Retrieved from https:// www.academia.edu/3841065/ ISLAMIC_FINANCE_INSTRUMENTS_AND_MARKETSViewpoint_Shariah_Law_Bringing_a_ New_Ethical_Dimension_to_ Banking

30. Qian, D. J., \& Velayuthan, S.

(2017). Conventional Banking and Islamic Banking: Do the Different Philosophies Lead to Different Financial Outcomes? Journal of Wealth Management and Financial Planning, 4, 3-14. Retrieved from https://mfpc.org.my/wp-content/ uploads/2019/03/3-14_OriginalResearch_Paper-1_ConventionalBanking-Islamic-Banking.pdf

31. Saif-Alyousfi, A. Y., Saha, A., \& Md-Rus, R. (2017). Shareholders' Value of Saudi Commercial Banks: A Comparative Evaluation between Islamic and Conventional Banks using CAMEL Parameters. Journal of Economics and Financial Issues, 7(1), 97-105. Retrieved from https://www.econjournals. com/index.php/ijefi/article/ view/4280/pdf

32. Salman, A., \& Nawaz, H. (2018). Islamic Financial System and Conventional Banking: A Comparison. Arab Economic and Business Journal, 13, 155167. https://doi.org/10.1016/j. aebj.2018.09.003
33. Sillah, B. M. S., Khokhar, I., \& Khan, M. N. (2014). The Performance of Saudi Banking Industry 2000-2011: Have the Banks Distinguished Themselves from One Another? International Journal of Financial Research, 5(2), 121-132. https://doi.org/10.5430/ ijfr.v5n2p121

34. Tahir, I. M., Bakar N. M., \& Haron, S. (2009). Evaluating Efficiency of Malaysian Banks Using Data Envelopment Analysis. International Journal of Business and Management, 4(8), 96-106. https://doi.org/10.5539/ijbm. v4n8p96

35. Varadi, V. K., Pradeep, M., \& Boppana, N. (2006). Measurement of Efficiency of Banks in India (MPRA Paper No. 17350). University Library of Munich, Germany. Retrieved from https://mpra.ub.uni-muenchen. de/17350/1/measurement_of_ banks.pdf 